\title{
Interactive comment on "Insights into seasonal variation of wet deposition over Southeast Asia via precipitation adjustment from the findings of MICS-Asia III” by Syuichi Itahashi et al.
}

Syuichi Itahashi et al.

isyuichi@criepi.denken.or.jp

Received and published: 2 April 2021

The comment was uploaded in the form of a supplement:

https://acp.copernicus.org/preprints/acp-2020-1179/acp-2020-1179-AC2-

supplement.pdf

Interactive comment on Atmos. Chem. Phys. Discuss., https://doi.org/10.5194/acp-2020-1179, 2020. 